\title{
Performance of Mangrove Species Planted inside Sonneratia apetala Buch.- Ham. Plantations in the Coastal Belt of Bangladesh
}

\author{
Sk. Ahiul Islam*, Md. Abdul Quddus Miah and Md. Ahsan Habib \\ Plantation Trial Unit Division, Bangladesh Forest Research Institute, Barisal, Bangladesh \\ Corresponding Author*: ahiulislam@yahoo.com
}

\begin{abstract}
An elimination trial with eleven mangrove species was conducted inside Sonneratia apetala Buch.Ham. plantations at Rangabali island of Patuakhali district and Char Kukri-Mukri island of Bhola district, Bangladesh to observe the site-suitability and growth performance of the species. The data on survival, height and diameter growth were recorded from 21 years old matured experimental stands. Some mangrove species showed promising growth performance in the coastal belt. The highest survival was found in Aegiceras corniculatum followed by Phoenix paludosa, Excoecaria agallocha, Heritiera fomes and Xylocarpus mekongensis at Rangabali island. In the Char Kukri-Mukri island, the highest survival was recorded for E. agallocha followed by P. paludosa, A. corniculatum, H. fomes and $X$. mekongensis. Considering the height and diameter growth, the most promising species was $E$. agallocha and then X. mekongensis, A. corniculatum, H. fomes and P. paludosa in both the islands. Therefore, these mangrove species can be planted inside $S$. apetala plantations for sustainability of coastal forests in Bangladesh.
\end{abstract}

Key words: Coastline, mangrove plantation, underplanting, survival and growth

\section{Introduction}

Bangladesh coastline is over $710 \mathrm{~km}$ long along the Bay of Bengal and comprises numerous char and offshore islands of varying sizes (Siddiqi, 2001). The greater part of the coastline was once without tree vegetation. Bangladesh Forest Department started coastal plantations on the newly accreted lands in 1966 with the primary objective to protect the lives and properties of the coastal people from cyclone and tidal bore (Das and Siddiqi, 1985). The objectives of coastal afforestation were then expanded to reclaim and stabilize the newly accreted lands, and production of timber and fuel wood (Saenger, 1987). Primarily, most of the commercial mangrove species were tried on newly accreted char lands. Among these species, only Sonneratia apetala Buch.-Ham. (keora) was the most successful species all along the coastline, while Avicennia officinalis L. (baen) was successful only in the eastern belt. S. apetala accounted $94.4 \%$ and A. officinalis $4.8 \%$ of the successful mangrove plantations (Siddiqi and Khan, 2004). A total of 0.192 million hectares mangrove plantations were raised in the newly accreted lands till 2013 (Hassan, 2013).

The coastal mangrove plantations are under severe threat due to geomorphic changes in the plantation sites, species succession and insect infestation of the established S. apetala plantations (Siddiqi et al., 1992; Siddiqi 2001). In many areas of the aged plantation sites, the forest floor rise up due to heavy sedimentation and resulted less inundation during full moon. Large scales stem borer attack in $S$. apetala plantations were observed for a long time (Baksha, 1996). The mortality of planted seedlings of this species in the coastal areas is also high (Siddiqi and Das, 1988). As a result gaps are created inside $S$. 
apetala plantations. Moreover, no regeneration appeared under these plantations due to rising of forest floor, compactness of soil and non-availability of seed source of other mangrove species. The life cycle of $S$. apetala is short and rotation period of felling is only $12-15$ years. After harvesting of matured $S$. apetala trees, there will be no second rotation forests for sustainability of this coastal forest. Therefore, underplanting trial in the existing $S$. apetala plantations with different mangrove species were laid out since 1990. The objective of this study was to find out suitable species for coastal plantation under the canopy of $S$. apetala forests for the establishment of long term permanent forest cover. There were some interim reports on this trial which showed the initial success and suitability of underplanting of some mangrove species (Siddiqi et al., 1992; Siddiqi and Khan 1996; Siddiqi, 2002). This paper describes sustainability (i.e. long term mangrove forest for climate mitigation and green shelter belt) and growth performance (i.e. survival, height and diameter) of 21 years old underplanted mangrove species inside $S$. apetala plantations in Rangabali island of Patuakhali district and Char Kukri-Mukri island of Bhola district, Bangladesh.

\section{Material and Methods}

Bangladesh Forest Research Institute carried out an elimination trial (i. e. choice of suitable species on the basis of their fast growth rates) along the coastline in two offshore islands, Rangabali under Patuakhali district and Char Kukri-Mukri under Bhola district, Bangladesh. Rangabali is located at latitude $21^{\circ} 92^{\prime} \mathrm{N}$ and longitude $90^{\circ} 45^{\prime} \mathrm{E}$. Char Kukri-Mukri is located at latitude $21^{\circ} 85^{\prime} \mathrm{N}$ and longitude $90^{\circ} 72^{\prime} \mathrm{E}$. The site condition of these two islands was more or less similar. The forest floor was inundated for a period of 6-7 months in a year at planting time in 1990. Annual rainfall varies from 2500-3000 mm and mean maximum and minimum temperature varies between $18^{\circ} \mathrm{c}$ and $32^{\circ} \mathrm{C}$ (Siddiqi, 2002). Soil of the sites is non-calcareous and silt-clay-loam. Soil salinity in the monsoon and dry season is remarkable varying between $0.3-4.2 \mathrm{dS} / \mathrm{m}$. Soil $\mathrm{pH}$ was slightly or moderately alkaline and varying between 7.5-8.0 (Siddiqi and Khan, 2000).

The commercially important 11 mangrove species namely Heritiera fomes (sundri), Excoecaria agallocha (gewa), Xylocarpus mekongensis (passur), Xylocarpus granatum (dhundul), Bruguiera sexangula (kankra), Aegiceras corniculatum (khalshi), Cynometra ramiflora (shingra), Ceriops decandra (goran), Lumnitzera racemosa (kirpa), Phoenix paludosa (hantal) and Nypa fruticans (golpata) were included in the underplanting trial (Table 01). In this study, underplanting means, some of the species were planted under the canopy of an established plantation. Among these planted species, 5 are tree, 4 are shrub and 2 are palm species. The seeds or propagules of these mangrove species were collected from the Sundarbans. Seedlings of all mangrove species except $N$. fruticans were raised in polybags of size $25 \mathrm{~cm} \times 15 \mathrm{~cm}$ or $15 \mathrm{~cm}$. x $10 \mathrm{~cm}$. Only $N$. fruticans seedlings were raised in muddy soil along the canal side or in the marshy land. Seedlings in the nursery were maintained in the nursery for about 10 months.

The plots were laid out in several sites such as Char Kashem under Rangabali island; and Char Zamir, Char Shafi and Zylar Khal under Char Kukri-Mukri island. The experiment was laid out in Randomized Complete Block Design with three replications. Each plot was planted with 100-121 seedlings at a spacing of $1.2 \mathrm{~m} \times 1.2 \mathrm{~m}$. The plots were fenced to prevent grazing animal interference up to five years of the plantations. Ten-month-old seedlings of the species were planted under 9-12 years old S. apetala plantations, except for $N$. fruticans seedlings, which were planted when three months old. Regular weeding (four weeding in first year and two weeding in subsequent years) was made up to five years after planting. The data in relation to survival, height and diameter growth were collected from the experimental plantations when the stand was 21 years. Recorded data were computed and analyzed using Excel and Minitab statistical packages. 
Table 01. Commercially important mangrove species that were tried in the experiment

\begin{tabular}{|c|l|l|l|l|l|}
\hline $\begin{array}{l}\text { Sl. } \\
\text { no. }\end{array}$ & $\begin{array}{l}\text { Common } \\
\text { name }\end{array}$ & Scientific name & Family & $\begin{array}{l}\text { Type of } \\
\text { plant }\end{array}$ & Main uses \\
\hline 1. & Sundri & Heritiera fomes & Sterculiaceae & Tree & $\begin{array}{l}\text { House construction, boat } \\
\text { building, electric poles, } \\
\text { hard boards and fuel wood }\end{array}$ \\
\hline 2. & Gewa & Excoecaria agallocha & Euphorbiaceae & Tree & $\begin{array}{l}\text { Matchsticks and boxes, } \\
\text { newsprints, other papers }\end{array}$ \\
\hline 3. & Passur & Xylocarpus mekongensis & Meliaceae & Tree & $\begin{array}{l}\text { Furniture; bridges and } \\
\text { house construction }\end{array}$ \\
\hline 4. & Dhundul & Xylocarpus granatum & Meliaceae & Tree & Furniture \\
\hline 5. & Kankra & Bruguiera sexangula & Rhizophoraceae & Tree & $\begin{array}{l}\text { Furniture, bridges and } \\
\text { house construction }\end{array}$ \\
\hline 6. & Khalshi & Aegiceras corniculatum & Myrsinaceae & $\begin{array}{l}\text { Shrub or } \\
\text { small tree }\end{array}$ & $\begin{array}{l}\text { Source of best quality } \\
\text { honey and fuel wood }\end{array}$ \\
\hline 7. & Shingra & Cynometra ramiflora & Leguminosae & $\begin{array}{l}\text { Shrub or } \\
\text { small tree }\end{array}$ & Fuel wood \\
\hline 8. & Goran & Ceriops decandra & Rhizophoraceae & $\begin{array}{l}\text { Shrub or } \\
\text { small tree }\end{array}$ & $\begin{array}{l}\text { Fuel wood, house posts } \\
\text { and charcoal }\end{array}$ \\
\hline 9. & Kirpa & Lumnitzera racemosa & Combretaceae & Small tree & Fuel wood and posts \\
\hline 10. & Hantal & Phoenix paludosa & Palmae & Thorny palm & Post and rafter for huts \\
\hline 11. & Golpata & Nypa fruticans & Palmae & $\begin{array}{l}\text { Recumbent } \\
\text { palm }\end{array}$ & Thatching for houses \\
\hline
\end{tabular}

\section{Results and Discussion}

Data on survival, height and diameter at breast height (DBH) of 21 years old mangrove species of this experiment were analyzed separately for Rangabali and Char Kukri-Mukri locations. The results of the study are described below for tree survival, tree height and diameter growth, growth performance and environmental benefits.

\section{Tree survival}

The highest survival was recorded for A. corniculatum (62\%) followed by P. paludosa (55\%), E. agallocha (54\%), H. fomes (49\%), X. mekongensis (48\%) at Rangabali. In Char-Kukri-Mukri, the highest survival were found for E. agallocha (70\%), followed by P. paludosa (59\%), A. corniculatum (46\%) H. fomes (30) and X. mekongensis (26\%) (Figure 01). Siddiqi and Khan (1996) reported the growth performance of mangrove species after 4 years and they found higher survival for E. agallocha (97\%) followed by $H$. fomes (93\%), P. paludosa (92\%) and A. corniculatum (68\%). Siddiqi (2002) again prepared a partial and interim report on survival, height and diameter growth of 11 mangrove species at the age of 8 years at Char Kukri-Mukri. He found higher survival for E. agallocha (90.3\%) followed by H. fomes (84.7\%), P. paludosa (84.7\%) B. sexanula (61.3\%) and X. mekongensis (58.3\%). 


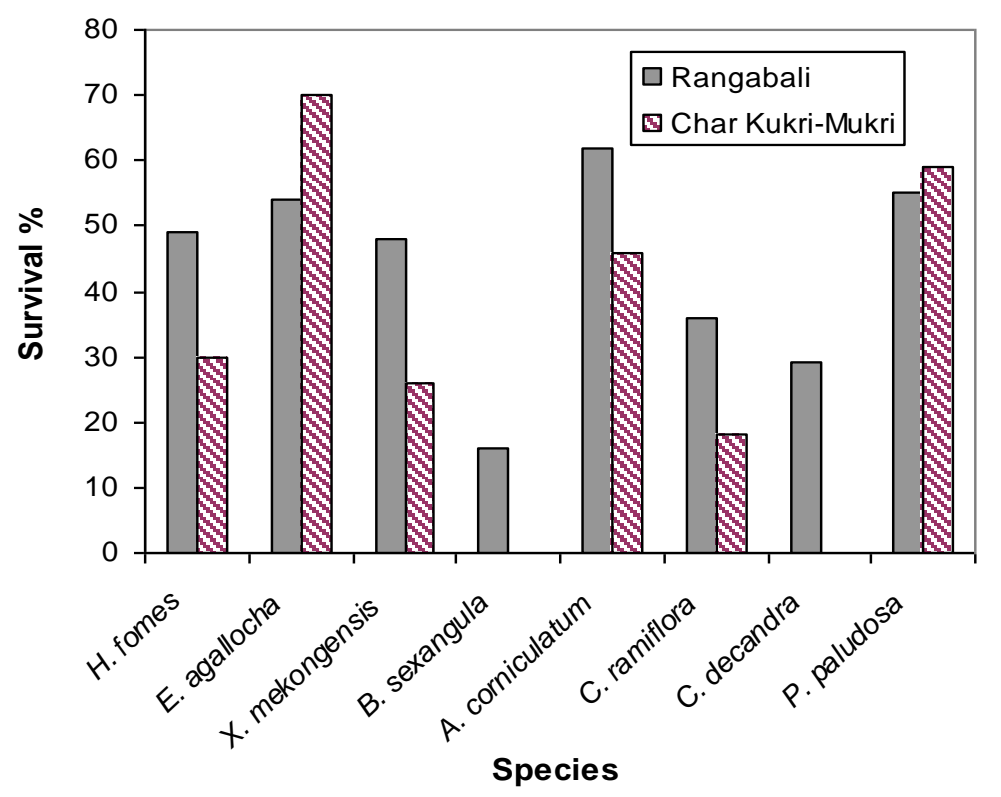

Figure 01. Mean survival percentage of 21 years old different mangrove species planted inside $S$. apetala plantations at Rangabali and Char Kukri-Mukri islands

\section{Tree height and diameter growth}

The highest mean height was recorded for E. agallocha $(11.73 \mathrm{~m})$ followed by $X$. mekongensis $(8.16 \mathrm{~m})$, $H$. fomes $(7.72 \mathrm{~m})$ and $A$. corniculatum $(7.10 \mathrm{~m})$ and $P$. paludosa $(6.71 \mathrm{~m})$ at Rangabali. The highest mean height growth was also recorded for E. agallocha $(10.04 \mathrm{~m})$ followed by $H$. fomes $(7.28 \mathrm{~m}), X$. mekongensis $(6.84 \mathrm{~m})$ and $A$. corniculatum (6.61) at Char Kukri-Mukri island (Figure 02). The highest mean DBH growth was recorded for E. agallocha $(10.76 \mathrm{~cm})$ followed by $X$. mekongensis $(8.79 \mathrm{~cm}), A$. corniculatum $(7.03 \mathrm{~cm}), H$. fomes $(6.51 \mathrm{~cm})$ and $P$. paludosa $(6.31 \mathrm{~cm})$ at Rangabali island. In the Char Kukri-Mukri island, the highest mean DBH growth was also recorded for E. agallocha $(8.51 \mathrm{~cm})$ followed by $A$. corniculatum $(7.96 \mathrm{~cm}), X$. mekongensis $(7.34 \mathrm{~cm})$ and $H$. fomes $(5.01 \mathrm{~cm})$ (Figure 03). Siddiqi and Khan (1996) found higher height growth for E. agallocha $(6.20 \mathrm{~cm})$ followed by $H$. fomes $(2.60 \mathrm{~cm})$ and $X$. mekongensis $(2.40 \mathrm{~m})$ in four years old stands. Siddiqi (2002) reported that maximum mean height was recorded for E. agallocha $(9.23 \mathrm{~m})$, followed by $H$. fomes $(5.33 \mathrm{~m})$, P. paludosa $(2.93 \mathrm{~m})$ and L. racemosa $(2.60 \mathrm{~m})$ in eight years old stands. He also found maximum DBH for E. agallocha $(7.33 \mathrm{~cm})$, followed by $P$. paludosa $(5.06 \mathrm{~cm})$ and $H$. fomes $(3.13 \mathrm{~cm})$ in the same experiment. In an observation of other plantations, Siddiqi and Khan (1990) found a height and diameter growth was $7.4 \mathrm{~m}$ and $11.14 \mathrm{~cm}$ for $E$. agallocha in 12 years old trees at Char Kukri-Mukri; 3.75m and $3.32 \mathrm{~cm}$ for E. agallocha in 11 years old trees at Char Kashem. 


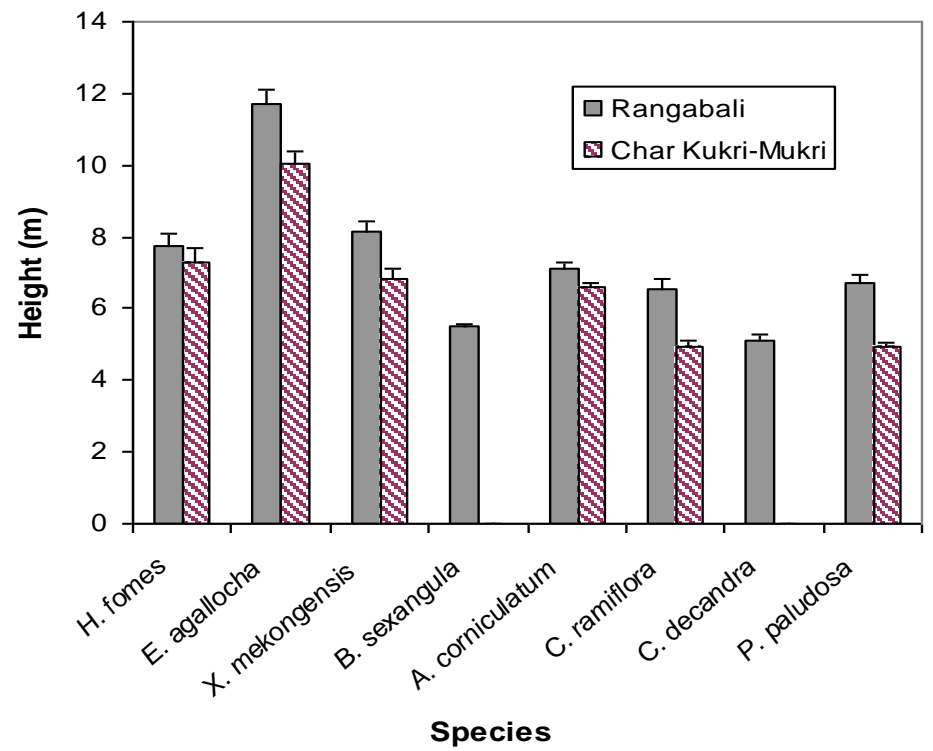

Figure 02. Mean height growth of 21 years old different mangrove species planted inside $S$. apetala plantations at Rangabali and Char Kukri-Mukri islands

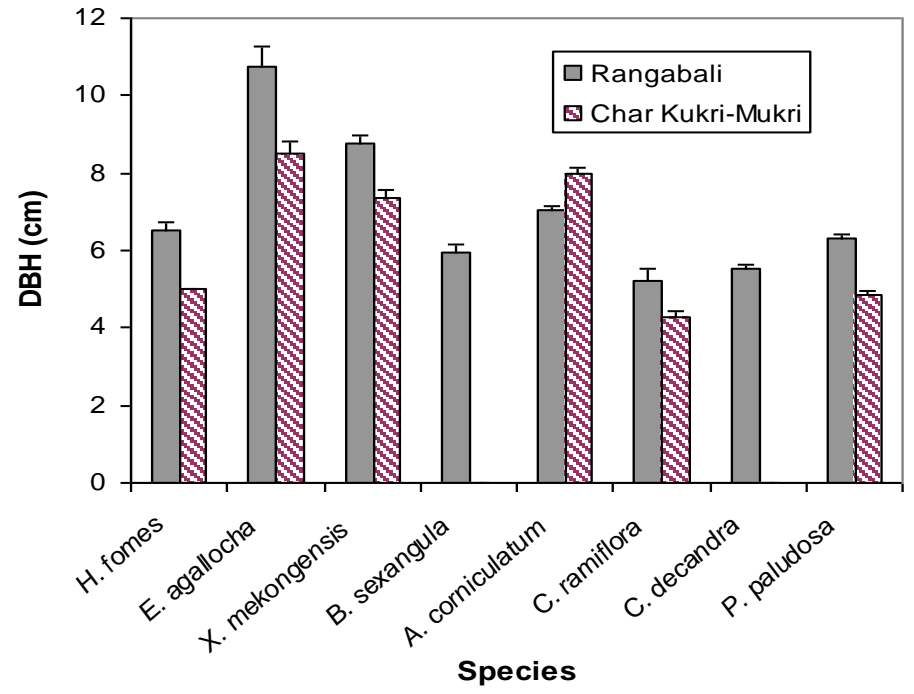

Figure 03. Mean diameter at breast height (DBH) of 21 years old different mangrove species planted inside $S$. apetala plantations at Rangabali and Char Kukri-Mukri islands 


\section{Growth performance}

In the coastline of Bangladesh, the planted mangrove species like E. agallocha, $H$. fomes, $X$. mekongensis, A. corniculatum and $P$. paludosa were found promising as underplanting at the age of 4 and 8 years (Siddiqi and Khan, 1996; Siddiqi, 2002). After 21 years, the results of survival, height and diameter growth data also revealed that E. agallocha are the most encouraging species and then $A$. corniculatum, $P$. paludosa, $H$. fomes and $X$. mekongensis were found better both in Rangabali and Char Kukri-Mukri island. Out of 11 species tried, 8 species were successful and 3 species were failed at Rangabali area but 6 species were successful and other 5 species fail to survive at Char Kukri-Mukri areas (Figure 01). X. granatum, L. racemosa and N. fruticans were failed in both the areas. In Rangabali area, $B$. sexangula and $C$. decandra showed very poor survival but totally failed at Char Kukri-Mukri. Grazing of domestic animal like cattle and buffalos has a highly detrimental impact on the successful establishment of mangrove plantations. Moreover, the introduced deer (Axis axis) in the Char KukriMukri island browsed seedlings of some palatable species like $X$. granatum and B. sexangula which ultimately affect survival of the species. The failure of $N$. fruticans is probably due to wrong site selection as the species needs 6-12 months regular inundation with muddy soil. Human interference and illicit felling (i.e. illegal tree cutting by thieves) in the experimental plots sometimes threatened their survival.

\section{Environmental benefit}

Bangladesh is one of the most vulnerable countries to the impact of climate change (MoEF, 2005; Rahman et al., 2008). The coastal area of Bangladesh is highly prone to cyclone and storm surges. It is believed that coastal forests serve as protective barrier (shelter belt) against natural disasters and those can minimize losses of lives and properties of coastal communities. Coastal forests also improve resilience and adaptation of coastal community against adverse impact of climate change. The introduction of other mangrove species inside $S$. apetala plantations will increase number of trees per unit area that will more capable of preventing wind velocity, tidal surges and other climatic events. Mangrove mixed plantations provides strong physical protection and some of the species can trap sediments by their root system that accelerates accretions and gradually stabilizes newly accreted lands. Introduction of more valuable of these mangrove species in the coastline following harvesting $S$. apetala forests creating second rotation long term permanent forests. In addition, natural regeneration of E. agallocha, $H$. fomes, and $P$. paludosa were observed in and around trial plots both at Rangabali and Char Kukri-Mukri areas. Fruiting of these species was started from 8-10 years old trial plantations and huge seedlings of these species were appeared in the areas after falling seeds on the forest floor. Presently, these trial plantations have also been serving as the mangrove seed sources in the coastal shoreline. This becomes an opportunity to develop second rotation dense vegetation naturally inside $S$. apetala forests. Findings of this research will help to make a plan for raising large scale plantations with these suitable mangrove species in the coastal belt of Bangladesh for increasing forest productivity and coastal biodiversity.

\section{Conclusion}

Bangladesh is a pioneer country in raising successful plantations with $S$. apetala along the shoreline and offshore islands. But these plantations are under tremendous pressure due to geomorphological changes in the plantation sites and human interferences. After harvesting this pioneer species, there will be no forests in absence of natural regeneration. Therefore, before harvesting a second rotation forests should be created. The promising species like E. agallocha, A. corniculatum, H. fomes, X. mekongensis and $P$. paludosa can be recommended for afforestation under the canopy of $S$. apetala plantation for sustainability of coastal forests. This coastal forest could be a green shelterbelt against all extreme weather events due to climate change in Bangladesh. 


\section{Acknowledgement}

Authors are grateful to Dr. Neaz Ahmed Siddiqi, Divisional Officer (Ret.), Plantation Trial Unit Division, BFRI for initiating an elimination trial of mangrove species inside $S$. apetala plantations. We are also thankful to Dr. P. Nandy, Divisional Officer (Ret.), Mr. Md. Rafiqul Islam, Research Officer (Ret.) and other field staffs of Rangabali and Char Kukri-Mukri Forest Research Stations of Plantation Trial Unit Division for their assistance in conducting this experiment.

\section{References}

Baksha, M. W. (1996). Beehole borer infestation in coastal plantations in Bangladesh and possible management options. Wallacena, 77: 17-20.

Das, S. and Siddiqi, N. A. (1985). The Mangroves and Mangrove Forests of Bangladesh. Mangrove Silviculculture Division. Bulletin No. 2. Bangladesh Forest Research Institute, Chittagong, Bangladesh. pp. 142.

Hassan, D. Z. (2013). Plants in Mangroves and Coastal Afforestation in Bangladesh. Dewan House, Ukilpara, Naogaon, Bangladesh. pp. 164.

MoEF. (2005). National Adaptation Programme of Action (NAPA). Ministry of Environment and Forest, Government of the People's Republic of Bangladesh. pp. 46.

Rahman, A., Rollinson, J. and Mohsin, N. (eds). (2008). Challenging Climates: Adapting to Change. Bangladesh Baseline Study, Bangladesh Centre for Advanced Studies, Dhaka, Bangladesh. pp.66.

Saenger, P. (1987). Bangladesh Mangrove Afforestation Project. Shedden Pacific Pty, Limited, Melborns, Australia. pp. 62.

Siddiqi, N. A. (2001). Mangrove Forestry in Bangladesh. Institute of Forestry \& Environmental Science, University of Chittagong, Chittagong, Bangladesh. pp. 201.

Siddiqi, N. A. (2002). Development and sustainable management of coastal plantations in Bangladesh. Journal of Asiatic Society of Bangladesh, Science, 28(2): 144-166.

Siddiqi, N. A. and Das, S. (1988). Effect of time and method of storage on the survival of uprooted keora (Soneratia apetala Buch-Ham) seedlings. Indian Journal of Forestry, 11(4): 326-330.

Siddiqi, N. A. and Khan, M. A. S. (1990). Growth performance of mangrove trees along the coastal belt of Bangladesh. Mangrove Ecosystems Occasional Papers. No. 8. UNDP/UNESCO REGIONAL MANGROVES PROJECT RAS/86/120. Thomson Press, Delhi. pp. 5-14.

Siddiqi, N. A. and Khan, M. A. S. (1996). Planting techniques for mangroves on new accretions in the coastal areas of Bangladesh. In: C. Field (Ed.), Restoration of Mangrove Ecosystems (pp. 143-159). International Society for Mangrove Ecosystems. Okinawa, Japan.

Siddiqi, N. A. and Khan M. A. S. (2000). Raising plantations of Phoenix paludosa - a mangrove palm in the coastal areas of Bangladesh. Journal of Asiatic Society of Bangladesh, Science. 26 (2): 259-264.

Siddiqi, N. A. and Khan, M. A. S. (2004). Human-induced succession of vegetation on new accretions in the coastal areas of Bangladesh. Journal of Tropical Forest Science, 16(2): 187-198.

Siddiqi, N. A., Khan, M. A. S., Islam, M. R. and Hoque, A.K.F. (1992). Underplanting-a means to ensure sustainable mangrove plantations in Bangladesh. Bangladesh Journal of Forest Science, 21: 1-6.

\section{Citation for this article (APA Style):}

Islam, S. A., Miah, M. A. Q. and Habib, M. A. (2015). Performance of Mangrove Species Planted inside Sonneratia apetala Buch.-Ham. Plantations in the Coastal Belt of Bangladesh. Journal of Bioscience and Agriculture Research 03(01), 38-44.

Retrieved February 25, 2015 from http://www.journalbinet.com/jbar-volume-03-issue-01.html 